\title{
Epidemiological and Clinical Aspects of Domestic Violence in Senegal
}

\author{
Mamadou Makhatr MBacké Leye ${ }^{1 *}$, Ibrahima Seck², Adama Faye², Mayassine Diongue1, \\ Ousseynou Ka ${ }^{3}$, Marème Sougou Ndeye ${ }^{1}$, Anta Tal Dia ${ }^{2}$
}

\author{
${ }^{1}$ Department of Preventive Medicine and Public Health, University Cheikh Anta DIOP of Dakar (UCAD), Dakar, Senegal \\ ${ }^{2}$ Department of Preventive Medicine and Public Health, UCAD, Dakar, Senegal \\ ${ }^{3}$ University of Bambey, Diourbel, Senegal \\ Email:^mamadou.leye@yahoo.fr,diongmaya@yahoo.fr,nmsougou@hotmail.com, solaye2@yahoo.com, \\ ibouseck@yahoo.fr,ousseyka@hotmail.com,diagodia@hotmail.com
}

How to cite this paper: Leye, M.M.M., Seck, I., Faye, A., Diongue, M., Ka, O., Ndeye, M.S. and Tal Dia, A. (2017) Epidemiological and Clinical Aspects of Domestic Violence in Senegal. Health, 9, 1404-1415. https://doi.org/10.4236/health.2017.910103

\section{Received: July 27, 2017}

Accepted: September 25, 2017

Published: September 28, 2017

Copyright (c) 2017 by authors and Scientific Research Publishing Inc. This work is licensed under the Creative Commons Attribution International License (CC BY 4.0).

http://creativecommons.org/licenses/by/4.0/

\section{Abstract}

Introduction: Despite being under-reported, domestic violence remains a significant challenge in Senegal. The aim of this study is to provide a descriptive analysis of the epidemiological and clinical factors characterizing domestic violence in Senegal. Methodology: A descriptive and retrospectively observational study was conducted. The data was collected from the court records of female victims of physical and/or sexual violence registered from 2006 to 2015. Female victims of physical and/or sexual violence at the hands of their husbands who had a court record at one of Senegal's high courts during this period were also included. All records that met the inclusion criteria were selected for the study, and the data was analyzed using Epi Info 3.3.2. Results: According to the court records of 148 female victims of domestic violence, the average age of the victims was $30.6 \pm 10.1$ years. More than $3 / 4$ $(76.4 \%)$ of the victims were housekeepers, $82.4 \%$ of whom were uneducated. The average age of the perpetrators was $40.4 \pm 11.4$ years, and they were self-employed in the informal sector in $47.3 \%$ of the cases. Additionally, more than $3 / 4(78.4 \%)$ of the perpetrators were uneducated. Eleven women ( $8 \%$ of the victims), were abused while pregnant. Physical violence was predominant (95.3\%), while those associated with sexual assault accounted for $4.7 \%$ of cases. Of the 7 recorded cases of sexual violence, 3 were cases of unwanted sexual touching, and all cases of physical violence were cases of assault and battery. The violence took place at the home of the perpetrators in $81.8 \%$ of cases. In $84.7 \%$ of the cases, victims received treatment and care within 24 hours or less. Among the victims, $73 \%$ showed clinical lesions. Contusions, hematomas and penetrating wounds were most frequent, representing $23.1 \% ; 19.4 \%$ and $13.9 \%$ of cases respectively. Conclusion: Despite the low number of cases reg- 
istered in the judicial system in the past ten years, much more violence is occurring without being denounced by the victims. Therefore, it seems appropriate to increase awareness within the community and break sociocultural barriers that hinder the recognition of women's rights in the couple.

\section{Keywords}

Violence, Domestic, Women, Couple, Prevention, Senegal

\section{Introduction}

According to the WHO's Global and regional estimates of violence against women, $35 \%$ of women worldwide have experienced physical and/or sexual violence perpetrated by their intimate partners, or sexual assault by others [1]. According to the United Nations Development Fund for Women (UNIFEM), this is a violation of their human rights, and "has the consequences of destroying lives, fracturing communities and hindering development", leading to "a frightening situation in terms of health and social consequences". Most societies prohibit such violence, but in reality it is too often ignored or tacitly condoned. No woman or girl in the world is immuned to gender-based violence. In sub-Saharan Africa, between $13 \%$ and $49 \%$ of women have been beaten or physically assaulted by a male intimate partner, with 5\% - 29\% reporting physical abuse in the year prior to the study [2]. Another study shows that $32 \%$ of African women have experienced serious physical violence by a male intimate partner during their lifetime [3]. In Senegal, not a day goes by without the press reporting at least one case of physical and/or sexual violence [4]. Indeed, in the late 1990 s and throughout the first decade of 2000, Senegal had taken a number of legislative and regulatory measures punishing violence against women, including marital violence. Despite these provisions, there has been a surge in cases of domestic violence in Senegal, which can take extreme forms, sometimes leading to death or other particularly serious consequences. [5] A multi-center study by UNIFEM showed that the number of cases of violence against women more than doubled within 5 years, from 157 cases in 2006 to 371 cases in 2010 [5]. Thus, the aim of this research is to study the epidemiological and clinical factors characterizing domestic violence in Senegal.

\section{Methodology}

\subsection{Study Location}

The Republic of Senegal is located in West Africa, between $12^{\circ} 8 \mathrm{~N}$ and $16^{\circ} 41^{\prime} \mathrm{N}$ latitude and $11^{\circ} 21^{\prime} \mathrm{W}$ and $17^{\circ} 32^{\prime} \mathrm{W}$ longitude. With a surface area of 196,722 $\mathrm{km}^{2}$, it is bordered on the north by Mauritania, on the east by Mali, on the south by Guinea and Guinea Bissau. To the west, Senegal is open to the Atlantic Ocean with $700 \mathrm{~km}$ of coastline. This study was conducted at Senegal's 11 high courts 
(TGI). The TGI provide data regarding not only the victims but also on the perpetrators. Located in the capital of the administrative region, the TGI have jurisdiction covering the entire region. The TGI may judge, without prejudice to special legal provisions all criminal offense other than those that fall within the jurisdiction of the departmental courts, including offenses committed by minors [6]. Therefore, physical violence such as assault and battery, rape, attempted rape, indecent sexual behavior, unwanted sexual touching and sexual harassment fall within the jurisdiction of the TGI.

\subsection{Study Type}

A retrospective and descriptive observational study was conducted from April 10 to May 09, 2017.

\subsection{Study Population}

The data was collected based on the court records of female victims of physical and/or sexual violence registered from 2006 to 2015.

- Inclusion criteria

All female victims of physical and/or sexual violence at the hands of their husbands who had a court record at one of Senegal's high courts (TGI) during this period were included.

- Exclusion criteria

All female victims of physical and/or sexual violence but whose court records were unusable (poorly filled in or damaged) were excluded.

\subsection{Sampling}

All court records that met the inclusion criteria were selected for the study.

\subsection{Data Collection}

A data collection form was designed based on the aims of the study and the data available in the victims' files. The files, namely the expert reports and the examination sheets of the female victims of violence, were the sources of data collection. A review of the expert reports and the examination forms was carried out. The forms allowed the study team to collect socio-demographic data from victims and perpetrators (age, occupation/profession, level of education); medical information of the victims (timing of consultation, clinical lesions); victims and perpetrators status (history of imprisonment, drug addiction and/or intoxication of the perpetrators at the time of the assault, pregnancy or physi$\mathrm{cal} / \mathrm{mental}$ disability in the victim); and the circumstances surrounding the assault (types, location, time, and weapons used).

\subsection{Analysis Methodology}

The data collected were entered, cleaned, and analyzed using the Epi Info 3.3.2 software. 
The first step was to describe all the different variables. For the quantitative variables, the mean, mode, median, standard deviation and outliers were calculated, while for the qualitative variables, the frequencies were calculated.

\subsection{Ethical Considerations}

This study was conducted with the permission of the ethics committee of Cheikh Anta DIOP Dakar University. Officials of the high courts also gave their approval to conduct the study in each court. The data collected in anonymity in the files of victims of domestic violence were kept confidential. Only the investigator and other study team members have access to the database.

\section{Results}

Data was collected from the court records of 148 registered cases of domestic violence.

\subsection{Socio-Demographic Characteristics of Victims}

The average age of the victims was $30.6 \pm 10.1$ years. The outliers were 13 and 70 years. The median and mode were 29 years and 35 years, respectively. The adult victims ( $\geq 18$ years old) were predominant, making up $91.2 \%$ of the total victims. More than $3 / 4(76.4 \%)$ of the victims were housekeepers, and they were not educated in $82.4 \%$ of cases (Table 1 ).

\subsection{Socio-Demographic Characteristics of Perpetrators}

The average age of the perpetrators was $40.4 \pm 11.4$ years. The outliers were 20 to 71 years. The median and mode were 39 and 40 years, respectively. All the perpetrators were adults ( $\geq 18$ years). They were self-employed in the informal sector in $47.3 \%$ of the cases, and more than $3 / 4(78.4 \%)$ of the perpetrators were uneducated (Table 1).

\subsection{Clinical Status of Victims and Perpetrators}

Eleven women ( $8 \%$ of total victims) were pregnant, and one was physically disabled at the time of the assault. Nine perpetrators had a history of imprisonment. The perpetrators were drunk and drugged at the time of the assault in $4.1 \%$ and $2 \%$ of cases, respectively. Among the perpetrators, one was mentally ill.

\subsection{Types of Violence}

Physical violence was predominant, accounting for $95.3 \%$ of all cases, and those associated with sexual assault accounted for $4.7 \%$ of cases. Of the 7 cases of sexual violence, 3 were cases of unwanted sexual touching, while all cases of physical violence were cases of assault and battery (Table 2).

\subsection{Circumstances Surrounding Assault}

Of these cases, body shots (kicking, punching, slapping etc.), improvised and 
Table 1. Socio-demographic characteristics of victims and perpetrators.

\begin{tabular}{|c|c|c|}
\hline & $\mathrm{N}$ & $\%$ \\
\hline & 148 & \\
\hline \multicolumn{3}{|c|}{ Victims } \\
\hline \multicolumn{3}{|l|}{ Age group } \\
\hline Adult ( $\geq 18$ years) & 135 & 91.2 \\
\hline Minor (<18 years) & 13 & 8.8 \\
\hline \multicolumn{3}{|l|}{ Occupation } \\
\hline Housekeep & 113 & 76.4 \\
\hline Self-employed & 21 & 14.2 \\
\hline Student & 5 & 3.4 \\
\hline Employee & 3 & 2.0 \\
\hline None & 3 & 2.0 \\
\hline Senior official & 1 & 0.7 \\
\hline Farmer & 2 & 1.4 \\
\hline \multicolumn{3}{|l|}{ Level of education } \\
\hline None & 122 & 82.4 \\
\hline Primary school & 7 & 4.7 \\
\hline Secondary school & 5 & 3.4 \\
\hline University & 2 & 1.4 \\
\hline Unavailable information & 12 & 8.1 \\
\hline \multicolumn{3}{|c|}{ Perpetrator } \\
\hline \multicolumn{3}{|l|}{ Age group } \\
\hline Adult $\geq 18$ ans & 148 & 100.0 \\
\hline \multicolumn{3}{|l|}{ Occupation } \\
\hline Self-employed & 70 & 47.3 \\
\hline Farmer & 38 & 25.7 \\
\hline Employee & 18 & 12.2 \\
\hline Junior official & 7 & 4.7 \\
\hline Senior official & 2 & 1.4 \\
\hline Student & 2 & 1.4 \\
\hline Laborer & 5 & 3.4 \\
\hline None & 6 & 4.1 \\
\hline \multicolumn{3}{|l|}{ Level of education } \\
\hline None & 116 & 78.4 \\
\hline Primary school & 12 & 8.1 \\
\hline Secondary school & 7 & 4.7 \\
\hline University & 13 & 8.8 \\
\hline
\end{tabular}

bladed weapons were used in $70.9 \% ; 37.8 \%$ et $7.4 \%$ of cases, respectively. The violence took place at the home of the perpetrator in $81.8 \%$ of cases, and more than half of the cases (51.4\%) occurred at night (Table 3). 
Table 2. Types of violence.

\begin{tabular}{ccc}
\hline & N & Percentage (\%) \\
\hline Types of violence & 141 & 95.3 \\
Physical & 7 & 4.7 \\
Physical and sexual & & \\
Types of sexual violence & 3 & 2.0 \\
Unwanted sexual touching & 2 & 1.4 \\
Indecent behavior & 1 & 0.7 \\
Rape & 1 & 0.7 \\
Attempted rape & & 100.0 \\
Types of physical violence & 148 & \\
Assault and battery &
\end{tabular}

Table 3. Circumstance surrounding assault.

\begin{tabular}{ccc}
\hline Circumstances surrounding assault & $\mathrm{N}$ & Percentage (\%) \\
\hline Type of weapon used & 105 & 70.9 \\
Body shots (kicking, punching, slapping etc.) & 56 & 37.8 \\
Improvised weapons & 11 & 7.4 \\
Bladed weapons & 1 & 0.7 \\
Boiling or caustic liquids & & \\
Scene of assault & 121 & 81.8 \\
In perpetrator's home & 16 & 10.8 \\
In victim's home & 5 & 3.4 \\
In the streets & 3 & 2.0 \\
At workplace & 2 & 1.3 \\
In the bush & 1 & 0.7 \\
At a friend's home & & \\
Time of assault & 72 & 48.6 \\
Daytime & 76 & 51.4 \\
Nighttime & &
\end{tabular}

Female victims sought medical attention within $50.9 \pm 254.5$ hours of the assault, with $84.7 \%$ of victims receiving medical attention within 24 hours or less. The outliers were 0 and 2160 hours. The median and mode were 10 and 24 hours, respectively.

\subsection{Clinical Lesions}

The victims had clinical lesions in $73 \%$ of the cases. Contusions, hematomas and penetrating wounds were most frequent, occurring in $23.1 \%$; $19.4 \%$ and $13.9 \%$ of cases, respectively (Table 4 ). 
Table 4. Clinical lesions of victims.

\begin{tabular}{|c|c|c|}
\hline Clinical condition of victims & $\mathrm{N}$ & Percentage (\%) \\
\hline \multicolumn{3}{|l|}{ Lesions } \\
\hline Yes & 108 & 73.0 \\
\hline No & 40 & 27.0 \\
\hline \multicolumn{3}{|l|}{ Types of lesions } \\
\hline Contusions & 25 & 23.1 \\
\hline Hematoma & 21 & 19.4 \\
\hline Penetrating wounds & 15 & 13.9 \\
\hline Generalised pain & 14 & 13.0 \\
\hline Ocular trauma & 8 & 7.4 \\
\hline Fracture & 7 & 6.5 \\
\hline Avulsions & 6 & 5.6 \\
\hline Multiple trauma & 5 & 4.6 \\
\hline Ecchymosis & 6 & 5.6 \\
\hline Sprain & 4 & 3.7 \\
\hline Epistaxis & 3 & 2.8 \\
\hline Strangulation & 3 & 2.8 \\
\hline Trismus & 2 & 1.9 \\
\hline Biting & 2 & 1.9 \\
\hline Head injury & 1 & 0.9 \\
\hline Mutilation & 1 & 0.9 \\
\hline
\end{tabular}

\section{Discussion}

\subsection{Sociodemographic Characteristics of Victims and Perpetrators}

The average age of the victims was 30.6 years lower than that found by Soumah MMM in his study in Dakar [7]. The victims are young, which is consistent with the data of Bah $\mathrm{H}$ et al in Conakry [8]. The average age of the abusive spouses was 40.4 years. The advanced age of these perpetrators partly explains their ability to violate their spouses. In terms of level of education, the majority of victims and perpetrators were not educated in $82.4 \%$ and $78.4 \%$ of cases, respectively. On the other hand, in the study by Lamy $\mathrm{C}$ et al, in $63 \%$ of the cases, female victims and their spouses had a relatively high socioprofessional level [9]. The results show that in our study, domestic violence affects mainly those in an illiterate environment. This violence is linked to the lack of knowledge of the rights of women by their abusive spouses and women's lack of decision-making power within the couple. These factors are deeply rooted in our society, thus exposing women to all forms of domestic violence.

\subsection{Types of Violence}

Domestic violence against women results in physical, sexual, and mental inju- 
ries, including threats, coercion or arbitrary deprivation of liberty in the public or private sphere [10]. The under-reporting of violence noted in our study is linked to sociocultural constraints where women have no decision-making power within the couple. However, in developed countries such as France, assault is reported much more frequently. Every year in France, 201,000 women are victims of physical and/or sexual violence perpetrated by their partner or ex-partner. At the same time, 83,000 are victims of rape or attempted rapes [11]. According to the assault type, all reported cases were ones physical violence, 7 of which were associated with sexual violence, such as attempted rape. This association of two forms of violence differs from what was revealed in Tunisia, where among the interviewees who were victims of domestic violence, $33 \%$ were subjected to both forms of violence [12]. Compared to men, women are twice as often physically abused in the household, and three times more often victims of unwanted sexual touching or forced sexual intercourse, both in and out of the household [8] [13]. This violence sometimes occurs while the victim is in a vulnerable situation (ex. during pregnancy, or while asleep) which can be an aggravating factor, or while the perpetrator is inebriated, mentally or emotionally unstable which can be a catalyzing factor.

\subsection{State of Victims and Perpetrators at Time of the Assault}

Husbands who were the perpetrators of the violence, were drunk at the time of the assault in $4.1 \%$ of the cases. The situation is even more alarming in the study by Manoudi $\mathrm{F}$ et al. where $27.3 \%$ of spouses who assaulted their wives were drunk. Alcoholism is an aggravating factor in domestic violence [14]. Perpetrators were under the influence of drugs in $2 \%$ of cases. The use of drugs makes spouses abusive towards their wives due to their lack of lucidity. Such violence is even more serious when it occurs on victims with a fragile state of health such as pregnancy. In our study, $8 \%$ of women were abused during their pregnancy. This rate is lower compared that found in the study by Boufettal $\mathrm{H}$ et al where it was estimated at $12.3 \%$ in Morocco [15]. In Ethiopia, nearly one fifth $(20.6 \%)$ of the women interviewed were physically abused by intimate partners during pregnancy [16]. The situation is all the more worrying in a study carried out in Brazil where $49.6 \%$ were subjected to violence during their pregnancy [17]. These abuses during pregnancy have adverse effects on women's health, namely gyneco-obstetric complications such as intra-uterine fetal death, or the death of the victim. The weapon used by the perpetrator determines the level of injury.

\subsection{Circumstances Surrounding Assault}

In our study, different weapons were used, but body shots were most frequently reported ( $70.9 \%$ of cases); similar to the study of Soumah MM where they accounted for $72 \%$ of cases [7]. Improvised and bladed weapons were used in our study in $37.8 \%$ and $7.4 \%$ of cases respectively. No guns were used by husbands to assault their wives. However, in the Luet SM et al. study conducted in Denmark, most victims were injured with bottles/glasses and blunted weapons $(44.8 \%$ vs. 
$28.2 \%$ ), while $24 \%$ were injured with bladed weapons, and $3 \%$ with firearms [18]. The situation is even more alarming in a study carried out in Rio Grande do Sul in Brazil where $41.1 \%$ were attacked with a firearm, and $37 \%$ with a bladed weapon [18]. In our study, assaults occurred in the perpetrator's home in $81.8 \%$ of cases, and in the victim's home in $10.8 \%$ of cases. These results demonstrate that domestic violence often takes place in a family environment. Women no longer feel safe within the family setting, because close relatives can exacerbate post-traumatic lesions [19]. The violence took place during the night in $51.4 \%$ of cases, and in the daytime in $48.6 \%$ of cases. On the other hand, in a study conducted at the gynecological-obstetric clinic Le Dantec, assaults that occurred during the day predominated. More than half of the victims (58.2\%) had been assaulted between 7 am and $6 \mathrm{pm}$, hence during working hours [20]. Conjugal violence occurring during the night can be more dangerous, as the female victim can be defenseless and readily surrenders to her attacker.

\subsection{Victim's Clinical Lesions}

Faced with these attacks, victims must resort to health facilities for early clinical treatment and care. In fact, female victims sought medical attention on average within 10 hours following the attack. The timing of treatment and care of 24 hours or less following the assault was observed in $84.7 \%$ of the cases. The relatively short delay between the time of the assault and accessing treatment and care improves the vital and functional prognosis of patients. Additionally, it allows for the quick diagnosis of lesions, which is evidence required for judicial proceedings, which is critical considering that the longer the delay, the more evidence can be concealed. Moreover, this percentage is lower than that defined in the study by Faye et al. where only $29.6 \%$ of patients were admitted to a health facility less than 24 hours after the attack [20]. This discrepancy may be explained by the fact that in our study, the women were all victims of physical violence and the severity of their clinical lesions prompted them to go to health facilities for consultation, whereas the victims of sexual abuse are usually late to go to health facilities, that is, beyond 24 hours. This delay makes it difficult for healthcare providers to describe forensic evidence in the medical certificates that are essential for the prosecution of the perpetrator. Hence the necessity of raising awareness on the risk of violence, particularly domestic violence within the populations, and to the importance of early admission to health facilities for the treatment and care of clinical lesions. In our study, contusions, hematomas and penetrating wounds were the most common types of lesions. In contrast, Leye MMM et al. found in their study that fractures were most common, i.e. $17 \%$ of cases, which demonstrates the severity of attacks perpetrated against women in the region of Tambacounda in the south-Eastern par of Senegal [21]. This fact is corroborated by other studies; Bénédicte Gatineau et al argue that this physical violence can have very serious consequences on the health of women. Almost half of physically abused women (46\%) reported having had bruises, about a quarter of them (23\%) had bleeding wounds, and $15 \%$ had a trampled or frac- 
tured limb [22]. These clinical lesions demonstrate the harmful consequences of the violence suffered by women at the hands of their spouses.

\subsection{Study Limitations}

The number of records from which data was collected should have been much higher considering that 148 reported cases of domestic violence is extremely low for a ten year period (2006 to 2015). This situation is explained in part by the fact that not all court records were systemically archived, which means that roughly 30 court records were unusable. On the other hand, it can explained by the under reporting of domestic violence cases which is related to some socio-cultural considerations, namely the weak decision-making power of women within the couple, shame, and fear of being stigmatized. Consequently, many abused women refrain from filing complaints against their spouses, and the couple's entourage intervenes to find an amicable solution. A population survey interviewing women in abusive relationships could have identified the medium and long term consequences of the violence. Psychological and economic violence were not taken into account in this study because they fall under the jurisdiction of the County Court. This study is quantitative, and there are very few qualitative studies that assess the community's attitude and perception of violence against women [23].

\section{Conclusion}

Domestic violence remains a major concern in Senegal, despite it has being under reported by female victims to medical and legal authorities. The fight against these forms of violence requires basic education for young people to protect them from environments characterized by alcohol consumption and drug-related delinquency, making them unable to assume their responsibilities in their relationships, and to recognize the rights of women. Promoting the education of girls, and providing women with income-generating activities will contribute to their empowerment and significantly reducing the violence they suffer at the hands of their intimate partners. These strategies to combat violence require a multisectoral approach to better defend the rights of women and girls in our society.

\section{Acknowledgements}

We would also like to thank the African Center of Excellence for Mother and Child Health (CEA SAMEF) and World Bank Group for the financial support needed to implement this study. Our thanks go to the head of service of Preventive Medicine and Public Health of the university Cheikh Anta DIOP of Dakar as well as the co-authors for their accompaniment in the realization of this work.

\section{Conflicts of Interest}

The authors do not declare any conflict of interest. 


\section{References}

[1] WHO (2013) Estimations mondiales et régionales de la violence à l'encontre des femmes. [Global and Regional Estimates of Violence against Women.]

[2] Viaux, J.-L. and Combaluzier, S. (2010) Un Néonaticide, un non-désir mélancolique: étude clinique de 12 cas. [Neonaticide, a Melancholic Non-Desire: Clinical Study of 12 Cases.] L'évolution Psychiatrique, 75, 3-17. https://doi.org/10.1016/j.evopsy.2008.02.014

[3] Watts, C. and Gossaye, Y. (2003) Withholding of Sex and Forced Sex: Dimensions of Violence against Zimbabwean Women, Women's Health and Life Events Study in Rural Ethiopia. Ethiopian Journal of Health Development, 6, 57-65.

[4] Leye, M.M.M., Faye, A., Wone, I., Diedhiou, D., Diongue, M., Niang, K., Seck, I., Ndiaye, P. and Tal Dia A. (2014) Étude des déterminants de viols chez les mineurs dans la région de Kolda au Sénégal. [Study of the Determinants of Rape in Minors in the Region of Kolda in Senegal.] Sante Publique, 26, 131-138.

[5] Niang, C.I., Diop, N., Diop, M.L., Sow, S., Guéye, M.A. and Sène, M.N. (2012) Rapport final de l'étude situationnelle sur les violences basées sur le genre dans les régions de Dakar, Diourbel, Fatick, Kaffrine, Kaolack, Louga, Saint-Louis, Thiès. [Final Report of the Situational Study on Gender-Based Violence in the Regions of Dakar, Diourbel, Fatick, Kaffrin, Kaolack, Louga, Saint-Louis, Thies.] ONUFEMMES- Senegal. Avril, 85 p.

[6] Gouvernement du Sénégal (2008) Rapport sur les cours et tribunaux. [Government of Senegal. Report on Courts and Tribunals.] $6 \mathrm{p}$.

[7] Soumah, M.M., Issa, A.W., Ndiaye, M., Ndoye, E.O. and Sow, M.L. (2015) Les violences conjugales à Dakar. [Domestic Violence in Dakar.] The Pan African Medical Journal, 22, 182.

[8] Bah, H., Abatty, O.C., Baw, A. and Soumah, M.T. (2008) Violences conjugales à Conakry. [Domestic Violence in Conakry.] Journal De Medecine Legale Droit Medical, 51, 221-225.

[9] Lamy, C., Dubois, F., Jaafai, N., Carl, T., Gaillard, P., et al. (2009) Profil clinique et psychopathologique des femmes victimes de violences conjugales psychologiques. [Clinical and Psychopathological Profile of Women Victims of Psychological Conjugal Violence.] Revue d'Epidémiologie et de Santé Publique, 57, 267-274.

[10] WHO (2009) Violence against Women. Fact Sheet 239. World Health Organization, Geneva.

[11] Simon, S. (2014) Violence contre les femmes: Implication de tous les acteurs. [Violence against Women: Involvement of All Actors.] Revue De L'Infirmiere, 205, 16-18.

[12] Ellali, I.A., Jellali, M.A., Gataa, R. and Mechri, A. (2015) Violence envers les femmes en milieu conjugal: Étude transversale au centre de planning familial de Monastir. [Violence against Women in Conjugal Environments: A Cross-Sectional Study at the Monastir Family Planning Center.] La Tunisie Medicale, 93, 516-522.

[13] Tournyol du Clos, L. and Le Jeannic, T. (2008) Les violences faites aux femmes. [Violence against Women.] Insee Première, 1180, 4.

[14] Manoudi, F., Chagh, R., Essoussi, M., Asri, F. and Tazi, I. (2013) Violence familiale. [Family Violence.] Encephale, 39, 271-277.

[15] Boufettal, H., Obaid, B., Belhouss, A., Hermas, S., Noun, M. and Samouh, N. (2012) Violence physique pendant la grossesse au Maroc. [Physical Violence during Pregnancy in Morocco.] Journal de Gynécologie Obstétrique et Biologie de la Reproduction (Paris), 41, 76-82. 
[16] Gebrezgi, B.H., Badi, M.B., Cherkose, E.A. and Weldehaweria, N.B. (2017) Factors Associated with Intimate Partner Physical Violence among Women Attending Antenatal Care in Shire Endaselassie Town, Tigray, Northern Ethiopia: A Cross-Sectional Study. Reproductive Health, 14, 76. https://doi.org/10.1186/s12978-017-0337-y

[17] Ribeiro, M.R.C., Da Silva, A.A.M., Alves, M.T.S.S.B., Batista, R.F.L., Ribeiro, C.C.C., Schraiber, L.B., et al. (2017) Effects of Socioeconomic Status and Social Support on Violence against Pregnant Women: A Structural Equation Modeling Analysis. PLoS ONE, 12, e0170469. https://doi.org/10.1371/journal.pone.0170469

[18] Ilha, M.M., Leal, S.M. and Soares Jdos, S. (2010) Women Interned Due to Aggression at an Emergency Hospital: The (in) Visibility of Violence. Revista Gaúcha de Enfermagem, 31, 328-334.

https://doi.org/10.1590/S1983-14472010000200018

[19] Fourn, E., Hountondji, T.A. and Ayatode, G.E.M. (2014) Quelques déterminants socio-culturels de l'éducation familiale basée sur la violence au Bénin. [Some Socio-Cultural Determinants of Family Education Based on Violence in Benin.] Revue du Cames, 1, 217-228.

[20] Faye, M.E., Gueye, S.M.K., Moreira, P.M., Moreau, J.-C., Diouf, A. and Traore, A.L. (2008) Profil épidémio-clinique et prise en charge des victimes d'abus sexuels à la clinique gynécologique et obstétricale du CHU de Dakar. [Epidemio-Clinical Profile and Management of Victims of Sexual Abuse in the Gynecological and Obstetric Clinic of the University Hospital of Dakar.] Journal de Gynécologie Obstétrique et Biologie de la Reproduction, 37, 358-364.

[21] Leye, M.M.M., Ndiaye, P., Ndiaye, D., Seck, I., Faye, A. and Tal Dia, A. (2017) Aspects épidémiologiques, cliniques et judiciaires des violences physiques faites contre les femmes à Tambacounda (Sénégal). [Epidemiological, Clinical and Judicial Aspects of Physical Violence against Women in Tambacounda (Senegal).] Revue D'Epidemiologie Et De Sante Publique, 65, 189-196.

[22] Gastineau, B. and Gathie, L. (2012) Violences conjugales à Antananarivo (Madagascar): Un enjeu de santé publique. [Domestic Violence in Antananarivo (Madagascar): A Public Health Issue.] Pan African Médical Journal, 11, 23.

[23] Semahegn, A. and Mengistie, B. (2015) Domestic Violence against Women and Associated Factors in Ethiopia: Systematic Review. Reproductive Health, 12, 78. https://doi.org/10.1186/s12978-015-0072-1

\section{Scientific Research Publishing}

Submit or recommend next manuscript to SCIRP and we will provide best service for you:

Accepting pre-submission inquiries through Email, Facebook, LinkedIn, Twitter, etc. A wide selection of journals (inclusive of 9 subjects, more than 200 journals)

Providing 24-hour high-quality service

User-friendly online submission system

Fair and swift peer-review system

Efficient typesetting and proofreading procedure

Display of the result of downloads and visits, as well as the number of cited articles

Maximum dissemination of your research work

Submit your manuscript at: http://papersubmission.scirp.org/

Or contact health@scirp.org 